\title{
SOMOGYI Aliz
}

\section{REFORMÉRETT KÖZÜGYEK}

\author{
Public Management:
}

ÚJ IRÁNYOK, ÁTALAKULÓ CÉL- ÉS ESZKÖZRENDSZER

Jelen tanulmány célja többszörös: részben e terminológiai káoszban való eligazodás megkönnyítése, másrészt az a nem titkolt szándék, hogy a közszféráról - gyakran nem alaptalanul alkotott - pejoratív (köz)megítélésünk némiképp javuljon a szektorális specifikumok felismerése és megértése által, végül a szektor reformpolitikai törekvéseinek átfogó jellegü bemutatása, kitérve az ,új közmenedzsment” (New Public Management) legfőbb üzenetének megismertetésére, annak elméleti gyökereire, kulcstényezőire.

Kulcsszavak: közszféra, reformtörekvések a közszektorban, állami szerepvállalás, természetes monopóliumok létjogosultsága, „Új közmenedzsment“ (New Public Management).

Közszektor, közszféra, közigazgatás, public szektor, közszolgálati ágazat vagy ezek további kombinációi: a „köznyelvi” terminológia e tárgykörre vonatkozó spektrumának teljes felsorakoztatása még talán véghezvihetö lenne, megkülönböztetésük azonban annál kevésbé. Szójátékkal élve „köztudomású”, mit jelentenek e „közkeletu”" kifejezések, de pontos tartalmukról fogalmunk sincs. Nem is csoda. A „köz” elötag ugyanis nemcsak a „közembert”, de magát a témával foglalkozó szakirodalmat is zavarba ejti. Hiszen sztereotípiákban (is) gondolkodunk és „,köztudatunkban” az él, hogy minden, ami „köz”, az „közösségi” és hogy minden, ami „közösségi”, az „köztulajdonban" van, de legalábbis bürokratikus, vagy valami olyan, ami nem lehet sem észszerü, sem gazdaságos, sem hatékony vagy épp modern. De semmiképp nem ideális. Még optimális sem. Vagy talán mégis?!...

\section{Közjavak, közszolgáltatások és sajátos vonásaik}

A közszféra tartalmi-terminológiai boncolgatását célszerű mindenekelőtt a szektor „termékeinek” körvonalazásával kezdenünk, annál is inkább, minthogy maga a közszolgáltatások, illetve közjavak egyértelmú definiálása is - a szolgáltatásokhoz hasonlóan - szá-

\footnotetext{
* Egyetemi adjunktus; Miskolci Egyetem Gazdaságtudományi Kar Vezetéstudományi Intézet; szvaliz@uni-miskolc.hu
}

mos nehézségbe ütközik. Félreértésre adhat okot a közösségi javak és szolgáltatások ,privát” termékektől, szolgáltatásoktól való elhatárolása, a köztulajdonban lévő intézmények, szervek feladatköre, a közigazgatási rendszer és a közszektor közé helytelenül tett egyenlőségjel.

Sárközy szerint a közszféra lényegesen szélesebb fogalom, mint a közigazgatás beleértendő a közalapítványoktól kezdve a különböző önkormányzati vállalatokig sokféle intézmény (Cseke, 2004: 16). A szektorális besorolás alapján ugyan a közigazgatás egyértelműen a szolgáltatásokkal azonosított tercier szektorba sorolandó és maga a közigazgatási gépezet a közszféra egy jelentős hányadát teszi ki, mégis csak egy szeletét: a közszektor túlmutat a közigazgatáson, magában foglalja a közfeladatokat ellátó szervezeteket, közszolgáltató vállalatokat, egyéb közintézményeket, Sárközy értelmezésében pedig még azokat az ügyvédi irodákat is, amelyek 99 százalékban az államnak dolgoznak (Cseke, 2004: 16). Tovább bonyolítva a „,nem minden rovar bogár, de minden bogár rovar"helyzetet, igaz a következő logika is: a közigazgatási tevékenység során nyújtott szolgáltatások egy jelentős része a közszolgáltatások körébe sorolandó, de nem minden közigazgatási aktus tekinthető közszolgáltatásnak, még akkor sem, ha azok tágabb értelemben közösségi célokat szolgálnak (pl. minisztériumok tájékoztatása az önkormányzati rendeletmódosításokról).

Ugyanígy téves azt képzelnünk, hogy a közösségi jellegú szolgáltatások mindegyike állami tulajdonban van, sőt, még további felosztásra ad lehetőséget az államigazgatási szervekhez való viszonyuk, közösségi 
funkciójuk, az igénybevevők köre, működési céljuk stb. A következőkben bemutatott és olykor inkonzisztensnek tűnő fogalmak nem jelentik az egymásnak való feltétlen ellentmondást, sokkal inkább az értelmezésben rejlő nehézségekre mutatnak rá.

Walsh szerint a közjavak olyan jószágok, amelyek „velük születetett tulajdonságuknál” fogva mindenki számára rendelkezésre állnak és amelyeknek egy személy általi használata nem zárja ki mások számára való elérhetőségüket (Walsh, 1995: 7).

Horváth $M$. szerint a közszolgáltatások alatt fogalmilag olyan feladatok ellátását értjük, amelyek adott feltételek között, valamilyen mértékig közösségi szervezést igényelnek és társadalmi közös szükségletek kielégítését szolgálják. A két feltételnek, a közösségi szervezésnek és a közös szükségletek kielégítésének együttesen kell fennállnia. Vagyis nem tekinthető közszolgáltatásnak, ha a közösségi szervezés nem közös szükségletek kielégítésére irányul (pl. az egyiptomi fáraók piramisépítése). Hasonlóképpen kívül esik a tárgyalt fogalomkörön, ha a közös szükségletek kielégítése nem közösségi szervezés keretében valósul meg (pl. a tengervíz használata, mindaddig, amíg a túlhasználat be nem következett) (Horváth M., 2002: 15).

Illés értelmezésében a közszolgáltatás közcélú, illetőleg közérdekű szolgáltatást jelent, mely egy nagyobb közösség minden tagjára nézve azonos feltételek mellett vehető igénybe (Illés, 2000: 9)

A közjavak és közszolgáltatások Davey-Péteri értelmezésében olyan javak és szolgáltatások,

- amelyek kivétel nélkül minden állampolgárt megilletnek, pl. rendőrségi szolgáltatások, közvilágítás, közparkok használata stb.;

- amelyeket egyénileg vesznek igénybe, de jóléti hatásuk társadalmi szinten jelentkezik, pl. oktatás, egészségügyi ellátás stb.;

- amelyek nélkülözhetetlenek az élet minőségéhez, de igénybevételük csak kizárólagos szolgáltatókon keresztül valósulhat meg, pl. ivóvíz-ellátás;

- amelyek nélkülözhetetlenek az élet minőségéhez, de az alacsony jövedelmű csoportok számára túl drágák ahhoz, hogy egyénileg elégítsék ki ilyen jellegű igényeiket, pl. tömegközlekedés, iskola stb. (Davey- Péteri, 1998: 212).

Átfogó értelemben véve közszolgáltatásnak tekintendő a közművek szolgáltatása a lakosság részére (Magyar Értelmező Kéziszótár, 1985: 790), míg a közigazgatás az állami igazgatás egyik speciális fajtája, amely az egész társadalomra kiterjedő, közhatalom birtokában végzett igazgatási tevékenység (Közigazgatási jog, 2001: 18). A közigazgatási jog ezen általános definíció mellett szervezéstudományi és jogtudományi (2) aspektusból is különbséget tesz (vö. Közigazgatási jog, 2001: 33).
A gyakorlatban nem mindig találkozunk a közjavak és közszolgáltatások tiszta formájával: a levegő egyértelmúen ebbe a fogalomkörbe sorolható, de többnyire olyan javakkal találkozunk, amelyeknek közösségi vonatkozásaik vannak, részben mégis magántulajdonnak tekinthetők (Walsh, 1995: 7). Walsh szerint minél komplexebb egy társadalom és az egyének minél több szállal kapcsolódnak egymáshoz, az interaktív hatásoknak köszönhetően az egyes javak, szolgáltatások „közösségi jelleget” fognak ölteni. Ezt támasztja alá az az érv is, mely szerint a lakásellátás, az oktatás, az egészségügy és egyéb szolgáltatások, amelyeket egyébként az egyének csak egy speciális köre vesz igénybe, ugyancsak bírnak a közjavak és közszolgáltatások jellemzőivel is (Walsh, 1995: 7).

A fenti definícióból következően a közszféra intézményeire általánosságban az alábbiak jellemzóek:

- gyakran nincs „tényleges” tulajdonosuk, így az állami, mint (rész)tulajdonosi elvárások nem egyértelműek;

- a szervezeti célrendszer konfrontálódhat a társadalmi elvárásokkal: az állami, össztársadalmi érdekek gyakran ellentétesek az intézményi, regionális stb. célokkal és/vagy az ügyfelek, állampolgárok elvárásaival;

- a közszolgáltatásokat ellátó intézmények a tipikus (vagyongyarapításra törekvő) szervezet formájában nem mindig szervezhetők meg (mivel itt nyereség nem mindig keletkezik), ezért ezek többnyire állami támogatással működő speciális közüzemek és közintézetek;

- a monopol- vagy kvázi-monopolhelyzet miatt nincs verseny, azaz nincs motiváló erő, amely hatékonyabb múködésre kényszerítené őket;

- az állami befolyás gyakran meggátolja az innovatív ötletek alkalmazását, a szükséges reformok megvalósítását;

- az állam normatív szabályozási hatalma sok tekintetben korlátot és egyoldalú függést okoz.

Láthatjuk, hogy a nem egyértelmű, tartalmuk, feltétel- vagy értelmezési rendszerük alapján egymástól sok tekintetben különböző meghatározások korántsem fedik egymást, de egy dolgot mindenképp alátámasztanak: az állam közszektorbeli létjogosultsága vitathatatlan, beavatkozási mechanizmusai a szociális ellátórendszerek hiátusai, demográfiai (pl. elöregedő társadalmak), jogi (pl. alapvető emberi jogok növekvő súlya) és gazdasági okokból fakadóan nélkülözhetetlenek.

\section{„Állami létjogosultság” a gazdaságban: természetes monopóliumok}

Walsh öt érvet sorakoztat fel az állam gazdaságitársadalmi szerepének alátámasztására (többek közt az externáliák vagy az információs aszimmetria megléte), 
melyek mindegyike a piac tökéletlen működéséből eredeztethető (vö. Walsh, 1995: 6-10), mértéke és milyensége azonban nem egyértelmű.

A jelenlegi államhatalmi rendszerek a történelem nyomait viselik magukon: a nemzetállamok fejlődésével együtt járó igazgatási feladatok gyarapodásával párhuzamosan nőtt az állam szerepe, de az igazi áttörés csak a polgárosodás során, a minden ellenőrzést nélkülöző rendőrállam kontrollált közigazgatásra való felváltásával következett be. A közszektor ekkor még szinte kizárólagosan a közigazgatást ölelte fel, beleértve az adott állam minden sajátos vonását. Ez a nemzetállamonként eltérő fejlődés a magyarázat a XXI. század történelmi-közigazgatási heterogenitására.

A sokféleség és egyediség közepette a középszintú közigazgatás alapján négy (európai) államtípust különböztetünk meg (vö. Torma, 2001: 160-164), melyek szoros összefüggésben a közigazgatási struktúrával, közvetett módon, mégis jelentősen determinálják az állam jelenlegi szerepét és befolyását a gazdasági életre, azon belül is leginkább a közszféra szervezeteire, intézményeire. Az eltérő államtípusok nem adnak lehetőséget az állam szerepének egyértelmű, általános meghatározására, bizonyos relációk azonban feltételezhetôk: a közigazgatási rendszer decentralizáltságának foka rugalmasabb mozgásteret jelent a magán- és közszféra együttműködésére, azaz a központi állam-igazgatástól való elhatárolódás mértéke a decentralizáció mértékével egyenesen arányos. A középszintű közigazgatás nagyfokú önállósága miatt ez elsősorban a (1) föderatív kormányzásra jellemző: a nemzeti alkotmányban lefektetett területek szövetségi kézben vannak (ezek általában a gazdasági élet legfontosabb területeit, a külügyeket érintik), míg bizonyos ügyköröket regionális (tartományi) szinten irányítanak ( $p l$. Németország és Ausztria). A (2) regionalizált államok kisebb mértékű, de még mindig jelentős közigazgatási önállósága a belga, olasz és spanyol gyakorlat alapján is változatos képet mutat. A (3) decentralizált államokban a legjelentősebb területek központi kézben vannak, regionális szinten elsősorban környezetvédelmi, infrastrukturális kérdésekkel foglalkoznak ( $p l$. Franciaország és Portugália). Az (4) unitárius államokban a középszint szerepe csekély, mely nagyon erős központi befolyás és irányítás alatt áll (pl. Dánia, Hollandia és Svédország).

Míg az államforma közvetlenül határozza meg a közigazgatási rendszerek működési sajátosságait, addig hatásuk a közszolgáltató vállalatok egy részére közvetetten is hatást gyakorol. Ez leginkább a köztulajdonban lévő (állami vagy önkormányzati) közszolgáltató vállalatoknál érvényesül, hiszen a tulajdon típusa alapvetően determinálja a „vállalkozás” milyenségét. Az állami kézben lévő közszolgáltató vállalatok többnyire természetes monopóliumként működnek: egyetlen szolgáltatóként vannak jelen a piacon, mert a kínálati oldal egyedüli szereplőjeként kisebb költség- gel tudják kielégíteni a keresletet, mint több szolgáltató együttes kapacitásainak felhasználásával.

A természetes monopólium a piacgazdaságok közismert gazdasági kategóriája: egy adott gazdasági tevékenység akkor van a természetes monopólium állapotában, ha átütő volumengazdaságosság és tevékenységi kör- gazdaságosság van jelen, aminek következtében az egyedüli kibocsátónak a teljes keresleti tartományban kisebb az átlagköltsége, mint két vagy több cég bármiféle output-kombinációjának (Illés, 2000: 16). A szakirodalom a fogalmat nemcsak vállalatokra értelmezi: „egy iparág akkor tekinthető természetes monopóliumnak, ha az adott áru vagy szolgáltatás előállításának költségei csupán akkor minimalizálhatók, ha előállításukat egyetlen vállalat végzi” (Viscusi Vernon - Harrington, 1995: 351).

A természetes monopólium fogalma sokak számára ellentmondásosnak tűnik: hogyan lehet egy monopólium természetes, ha versenytárs híján visszaélhet kivételezett helyzetével vagy épp ezt elkerülendő, sokkal inkább érvényes rá az erős állami szabályozottság, mint a piacgazdaság bármely más szereplőjére? Az ellentmondás az állami beavatkozási mechanizmusokkal oldható fel: a nagyfokú reguláció egyrészt az árszabályozást, másrészt a társadalmi igények minél jobb kielégítését célozza meg. Ugyan a természetes monopóliumok mindenképp állami szabályozás alá esnek, tulajdonosuk nem minden esetben az állam: az Amerikai Egyesült Államokban a természetes monopolhelyzetben lévő vállalatok szinte kivétel nélkül magántulajdonban vannak, az állam kizárólagosan szabályozó és felügyelő szerepet tölt be. Az európai országok többségében fordított a helyzet, melynek előnye, hogy a megtermelt profit az államháztartási büdzsét gyarapítja, azonban az esetleges veszteséget az adófizető állampolgárok szenvedik el.

Az elmúlt években Európa-szerte elmozdulás történt az állami monopóliumok liberalizálásának irányába, melyre sikeres és a társadalom szempontjából inkább hátrányos eseteket egyaránt találunk: a telefontársaságok monopolhelyzetének megszűnése a legtöbb országban árcsökkenést eredményezett, míg az angol vasút privatizációja után az átlagos késés időtartama az állampolgárok nem kis bosszúságára megsokszorozódott. Egy dolgot mindenképp leszögezhetünk: természetes monopólium még soha nem ment tönkre, hiszen állami tulajdonlás esetén „,kritikán aluli gazdálkodás" a nem titkolt politikai érdekeknél fogva sem történhet meg (képzeljük csak el, mi történne, ha kialudna a villany, vagy megszakadna minden telefonos kapcsolat...), liberalizált piaci viszonyok között pedig a hatékony múködtetés és folyamatos fejlesztés a vállalati versenyképesség megőrzésének alapvető feltétele.

$\mathrm{Az}$ állam szerepét az európai nemzetállamokban jelentkező kettős kihívás miatt mindenképp újra kell gondolni: 
- kívülről a multinacionális cégek, a liberalizált kereskedelem, a transznacionális tőkemozgás és a globalizációs szerveződések kérdőjelezik meg a szuverenitás hagyományos értelmezését,

- belülről a politikai elitbe vetett bizalom hanyatlása, ezzel együtt a széleskörű legitimitás hiánya a kerékkötője az átfogó reformoknak.

A közszféra átalakítása tehát nem az állam szerepének megszűnését, hanem az állammal való újfajta kapcsolat kialakitását kívánja meg, melyben az állam gondoskodó szemléletét egy esélyteremtő, minél nagyobb társadalmi csoportokat bevonni képes, partnerséget kínáló koncepció váltja fel (Dessewffy - Pulai, 2005: 20).

\section{Reformtörekvések a közszektorban: a változást indukáló társadalmi és gazdasági folyamatok}

A világ országainak kormányzati-közösségi szektoraiban az utóbbi mintegy húsz évben kirajzolódó általánosabb fejlődési tendenciákat szemlélve azok legjelentősebb elemének az ún. Új Közmenedzsment (New Public Management, későbbiekben NPM) ,mozgalom" tűnik (Hajnal, 2004: 8), mely az állam újbóli „feltalálását" célozza meg (Osborne - Gaebler, 1992). Ennek középpontjában olyan célkitűzések állnak, mint a közszektor hatékonyságának, eredményességének és fogyasztó-orientációjának növelése, az állam leépítése, a privatizációra és az ún. piaci típusú mechanizmusokra való fokozott támaszkodás, illetve a kormányzás problémáinak újszerű, menedzsertípusú megközelítése, és a magánvállalati menedzsmentben alkalmazott technikák és filozófia fokozott átvétele (Hajnal, 2004: 8).

Mint minden, akár csak némileg is jelentős tér- és időbeli érvényességű, gyakorlati orientációt nyújtó szellemi-politikai áramlatot, úgy az NPM-et is lehetetlen egyetlen „ősforrásra” visszavezetni. Mindazonáltal célszerü az NPM-et a hetvenes-nyolcvanas évek fordulója világgazdasági szerkezetváltásának-receszsziójának, illetve a legtöbb angolszász országban ezzel összekapcsolódó jobboldali, neokonzervatív-neoliberális politikai fordulatnak a közegéből kiindulva megközelíteni (Hajnal, 2004: 21). „Az úttörők egyes angolszász országok voltak, ...majd a tapasztalatok, ha nem is ugyanolyan intenzitással, tovagyűrűztek a frankofon befolyási övezetű régiókra. Továbbá ugyancsak jelen vannak a latin-amerikai országok közigazgatási reformjaiban is." (Horváth M., 2002: 59).

Az új közmenedzsment világszerte elterjedt hullámai Új-Zélandról indultak, ahol az emberek Angliának köszönhetően évtizedeken keresztül gazdasági biztonságban érezhették magukat. A három és fél millió újzélandi lakosra 60 millió juh jutott, melyet többségében Anglia fix áron vásárolt fel. Az Európai Unióhoz való csatlakozása által Anglia elvesztette ,átvételi kötelezettségét", így az új-zélandi gazdaság nemzetközi versenynek lett kitéve. Az akkori konzervatív kormány első reakciója ,a nem megfelelő gyógyszerek még további beszedése volt". A szubvenciók megnövekedtek, a piaci akadályok felerősödtek, a szociális segélyeket továbbfejlesztették egészen addig, míg végül az ország teljes mértékben fizetésképtelenné vált. Az 1984-es választások eredményeztek forradalmi áttörést. Az új kormánnyal a politikai tisztviselők egy teljesen friss, fiatal generációja került hatalomra: az „ôsi érdekektől” való politikai függetlenség egyedülálló reformhoz vezetett (Schedler, 2004).

A közszektorban végbemenő reformok okai az újzélandi példán túl a 70 -es évek végén bekövetkezett változásokra vezethetők vissza: az olajár-sokk következményeként kialakult gazdasági válság, és az ennek eredményeképp létrejövő növekvő munkanélküliség, csökkenő állami bevételek és emelkedő szociális kiadások megerősítették azokat, akik a bürokratikus rendszer korábbi funkcionális hiányosságait kritizálták (Budhäus/Grüning, 1998: 4).

Az ennek hatására kialakult, a közszektor reformjára vonatkozó igény a tudományos élet szereplőit is aktivizálta: Amerikában, Ausztráliában, a Benelux-államokban, Németországban és Franciaországban számos elméleti nézet látott napvilágot a közigazgatásijogi szektor reformját illetően (Brunner - Salten, 2003: 41). A tudományos szakértők mellett maga a közszektor is jelentős átalakuláson ment keresztül elsősorban a fogyasztói értékrendváltozás eredményeképp. A piacgazdasági szolgáltatás- és teljesítménynyújtásban bekövetkezett minőségjavulásnak köszönhetően megnőtt az állampolgárok elégedetlensége a közszolgáltatásokkal, közvetve pedig az állam „,gondoskodó funkciójával" szemben, valamint az igény a közszektorbeli teljesítések minőségére vonatkozóan.

A NPM ezen túlmenően az egyes kormányok média és választópolgárok felé irányuló PR-kommunikációjának is egyik lényeges, helyenként és időnként középponti elemeként is megjelenik (Hajnal, 2004: 8). Az Egyesült Államokban a szövetségi kormányzás, az egészségügy és az oktatás menedzsmentje az elnök politikai sikerességének központi eleme. A volt Szovjetunió és Kelet-Európa egykori kommunista kormányrendszereiben óriási problémák jelentek meg az alapvető szolgáltatások, az egészségügy, a lakás- és ivóvízellátás, valamint a közszolgáltató vállalatok privatizációja során. A kevésbé fejlett országokban gazdasági nehézségek és külső nyomások vezettek az állam gazdaságban betöltött szerepének újbóli felülvizsgálatához. Ausztráliában és Új-Zélandon egy mikroökonómiai reformprogramot vezettek be, ahol a változások alapjául a közszolgáltatások működése szolgált. Az európai országokban ugyan eltérő mértékben, de a közszektor menedzsmentjének egy új megközelítése nyert teret. A kormány önmenedzselését szorgalmazó fejlődés során talán leginkább Anglia jelenti a forradalmi változások helyszínét (Walsh, 1995).

A közszektor reformja teljes mértékben sehol nem zárult le, sőt, a poszt-szocialista országokban a demok- 
ratikus államiság megteremtésével szinte párhuzamosan, csak az elmúlt egy-két évtizedben indultak el a szektort érintő újragondolások, fejlesztési törekvések a nemzetállammal szemben még határozottabb állampolgári igények megfogalmazódásával: az előző rendszerből ránk maradt, paternalista, gondoskodó államszemléletet kell felváltani az átlátható, esélyteremtô, partnerséget kínáló állam koncepciójával (Dessewffy Pulai, 2005: 20).

\section{Elméleti gyökerek}

A szakirodalomban nagy az egyetértés abban, hogy az új közmenedzsment ugyan nem rendelkezik egységes tudományos bázissal, alapjai azonban két elméleti nézetből eredeztethetők: egyrészt az institucionalista közgazdaságtanból származó Public Choice Theory-ra („közösségi választások elmélete”), másrészt az ún. menedzserializmusra (Thom - Ritz, 2000: 24).

A Public Choice gazdaságtana átfogó teória, amelynek alapkoncepcióját a közszolgáltatások versenyszféra szerinti kezelése jelenti. Eszerint a közszolgáltatások éppúgy áruként jelennek meg a piacon, mint a klasszikus értelemben vett termékek (Horváth M., 2002: 26), az emberek pedig racionális és haszonmaximalizáló döntéshozók (Mueller, 1989: 1). A polgárok, mint közösségi fogyasztók természetesen költségeik minimalizálására törekszenek. Ezt elméletig aszerint teszik, hogy hol jutnak hozzá előnyösebben, figyelemmel a díjakra, a helyi adóterhekre és a lokális körülményekre (Horváth M., 2002: 26). A politikusok döntési magatartásai a végrehajtó hatalom és „hivatalnokok” egyéni preferenciájának összesített eredménye. Olyan „,egyéni haszon-, illetve büdzsémaximalizáló bürokraták", akik a politikusok döntési magatartását erősebben befolyásolják együttesen, mintha azt egyénileg tennék. A politika ily módon veszélyeztetett elsőbbségének visszaállítása és a bürokrácia monopolhelyzetének megakadályozása érdekében egyrészt nagyobb versenyre van szükség a hivatalok között, másrészt a közintézményekben dolgozók teljesítményarányos bérezésére (Thom - Ritz, 2000: 25).

A NPM másik alappilléreként kikiáltott elmélet, az ún. menedzserializmus, Pollitt nevéhez füződik (vö. Pollitt, 1990: 27), mely nem egy meghatározott gondolatmenetet, sokkal inkább hittételeket és gyakorlati praktikákat, azaz menedzsmentelvek speciális problémákra való alkalmazását hirdeti (Kieser, 1998: 65). Alapfeltétele egy elegendő nagyságú cselekvési tér megléte a szociális fejlődés elérése, illetve a szociális problémák haté-

Forrás: Hill, 1997: 21 kony megoldása érdekében. Ez teszi lehetővé intézményi szinten a professzionális menedzsment kiépítését, amely mint központi szervezeti forma érvényesül a termelékenység növekedésének elérése során. A termelékenység növekedése az alkalmazott technológiáknak köszönhetően valósul meg, mely végső soron szociális fejlődéshez vezet. A menedzserializmus ezen gondolatmenete a NPM keretein belül a hatalom dekoncentrációját eredményezi, mely a közigazgatási decentralizáció, dereguláció és delegáció által érhető el. További következményei a folyamatnak a teljesítmény- és célegységesítés fejlődése, új vezetési stílusok, teljesítményalapú javadalmazási rendszer és a humán erőforrás menedzsment fejlődése (Thom - Ritz, 2000: 27).

A közszektorral szemben támasztott követelmények a 60-70-es évek társadalmi, gazdasági fordulataival együtt gyökeresen megváltoztak (1.ábra). Az ideológiai gyökerek gyakorlatban való „tiszta” alkalmazása helyett a NPM a két megközelités lényegi pontjait ötvözve a kollektív haszonszerzést a közszektor szereplőinek racionális döntései által, a verseny kiélezésével, a teljesítményelv alkalmazásával, valamint az eredményorientáció és a decentralizáció erősítésével viszi véghez.

\section{Új közmenedzsment (New Public Management)}

Az először a 90-es évek elején használt „új közmenedzsment" a közszektor azon szükségletét fejezte ki, mely a régi közigazgatási viszonyokban létrejövő réseket hivatott kitölteni. Ennél fogva vállalatgazdaságtani szempontból egy reformorientált vezetéstanról van szó a közszektor számára (Thom-Ritz, 2000: 24).

Zielinski közmenedzsment alatt olyan modellt ért, mely szerint a közszféra intézményei (közigazgatási intézmények, közszolgáltató vállalatok, non-profit szervezetek) belső igazgatási folyamataikat és szervezeti struktúrájukat az eredmények és hatások tekintetében a magángazdaság menedzsment-technikáját követve, illetve arra támaszkodva újonnan rendszerezik.

\section{1. ábra}

Megváltozott körülmények és elvárások a közszekorban

\begin{tabular}{|lll|}
\hline \multicolumn{2}{|c|}{ A közszektorral szemben támasztott követelmények, elvárások } \\
\hline \multicolumn{1}{|c|}{ Korábban } & \multicolumn{1}{c|}{ Napjainkban } \\
\hline Átláthazó tények és problématerületek & $\rightarrow$ & Átláthatatlanság és komplexitás \\
Relatíve állandó kapcsolatok & $\rightarrow$ & Dinamikus változás, átalakulás \\
Világos hatáskapcsolatok & $\rightarrow$ & Hálózatosodás multikauzalitás \\
Az „elkülönítés” alapján jogstruktúrák & $\rightarrow$ & Kombinációk és alternatívák \\
Egyértelmű társadalmi célcsoportok & $\rightarrow$ & "Rövid életű” célcsoportok \\
Politikai kiszámíthatóság & $\rightarrow$ & "Nem-választók”, ,"cserélődő-választók” \\
Autoritás & $\rightarrow$ & Értékváltozás, értékközömbösség \\
Szociokulturális stabilitás & $\rightarrow$ & Demográfiai változások \\
\hline
\end{tabular}


Ennek alapján a közmenedzsmentben a költség-tudatosság és a demokrácia összekapcsolódik (Zielinski, 2003: 41). Horváth M. átfogó ágazatpolitikai kezdeményezésről beszél (Horváth M., 2002: 59), mások a piacgazdasági elgondolás közigazgatásban való diadalmenetként látják a jelenséget. Dunleavy - Hood szerint új közmenedzsment a közigazgatási szervek reorganizációjának módját leíró összefoglalás, mely a közszféra irányító, beszámoló és elszámoló szemléletét az üzleti élet módszereihez közelíti (Dunleavy - Hood, 1994: 9), míg König a gazdaság elveinek az állam felett aratott győzelmeként definiálja a fogalmat (König, 1995: 37).

A „mozgalom” újdonsága a közszféra és a magánszektor értékeinek újfajta kapcsolása a menedzsment szerepének kialakitásában. A magánszektorra jellemző értékeket bevitték a közszektorba. Tették ezt úgy, hogy a közfeladatok megszervezése, mint tevékenység elé célként magánigazgatási, tehát piaci vagy ahhoz hasonló értékeket állítottak. Ily módon kialakult egy, a hagyományos igazgatási modellel szembeállítható menedzsment, amelyik struktúrájában, megoldásaiban, személyzetének alkalmazását tekintve, valamint kultúrájában valóban merőben új és szokatlan rendszert alkotott. Ennek lényege a hierarchizált, bürokratikus és központosított szerkezettel szemben a kevésbé merev rendszert alkotó, de inkább az elérendő célra koncentráló, decentralizált megoldások kialakítása volt (Horváth M., 2002: 59). Az eredményorientált közigazgatás-vezetés egy olyan irányítási modell a politika és a közigazgatás számára, amely leginkább az ügyintézés eredményeire irányítja figyelmét. Célja az eredményorientáció bevezetése a politika és közigazgatás minden döntési mechanizmusában és eszközrendszerében. A modell nem egy merev koncepció, sokkal inkább egy vezetési elv, melyet mindig az adott környezethez kell/lehet illeszteni (Schedler, 2004).

$\mathrm{Az}$ új közmenedzsment tehát menedzsmentszempontokat érvényesitve a magánszektor mellett az állami szerepvállalás megörzésének szükségességét hirdeti a gazdasági életben a maga sajátos döntéshozatali és -megvalósitási folyamatai által (Reinermann, 1998: 39). Alkalmazása során:

- Csökken, de legalábbis átalakul az állami beavatkozás mértéke;

- A tevékenységi kör egy részének kihelyezésével kiéleződik a verseny, ezáltal előtérbe kerül a teljesítményelv;

- A tevékenységi kör leszűkítésének és a projekt-jellegű munkavégzés felerősödésének hatására a nagyságuknál fogva merev szervezetek helyett kisebb méretű, rugalmasabb intézmények, vállalatok jönnek létre;

- A hagyományos (sokszor bürokratikus) szervezeti felépítést korszerúbb konszern-struktúra váltja fel, ezáltal felerősödik az eredmény- felelősség- motiváció hármasának hatásmechanizmusa;
- Az érdekeltek és a felelősök olyan intenzíven kapcsolódnak egymáshoz a tartós és összetett üzleti folyamatokban (beleértve az állampolgárok/ügyfelek számára előállított/nyújtott termékeket és szolgáltatásokat), hogy ennek megfelelően a hatáskör és a felelősség is kiterjed (Brunner - Salten, 2003: 52-53);

- A szervezeti döntési centralizációt decentralizáció váltja fel;

- Új vagy addig a közszférában nem alkalmazott menedzsmenttechnikákat vezetnek be;

- A merev szabályrendszer helyett a megbízásos szerződések biztosítják a környezeti feltételekhez való magas(abb) fokú alkalmazkodást, ahol a szabályszerűség mellett az eredményességre is nagy hangsúlyt helyeznek (vö. Brunner - Salten, 2003: 52-53);

- Az emberi tényezők felértékelődése az új(szerű) vezetési stílus mellett az ügyfélorientáció megnövekedett jelentőségében is testet ölt: az (állam)polgár-orientáció a közszektor paradigmaváltásának, illetve az egyén szempontjából a teljesítendő feladatnak, szolgáltatásnak szimbólumaként jelenik meg (Zielinski, 2003: 20).

$\mathrm{Az}$ új közmenedzsment legfőbb elemeit a vezetési funkciókkal és az irányítási elvekkel szoros összefüggésben Damkowski-Precht nyomán az 1. táblázatban foglalom össze.

\section{Paradigmaváltás: érték- és eredményorientáció}

A NPM központi gondolatmenete közgazdasági jellegénél fogva: a lehető legkisebb befektetéssel a lehető legnagyobb haszon elérésére (Zielinski, 2003: 20). Alkalmazása ugyanakkor értékrendbeli átalakulást kíván meg, illetve új irányítási formák bevezetésével vihető sikerre. A NPM által hirdetett új értékek feloldják a megmerevedett közigazgatási, közszolgáltatói struktúrát és kultúrát (Thom-Ritz, 2000: 3), a megváltozott társadalmi elvárásokhoz idomuló feladatteljesítés és ügykezelés pedig új alapokon nyugszik: nem kínálat(,azt kínáljuk, amink van”), hanem eredményorientált (Zielinski, 2003: 18). Ez az értékrendbeli paradigmaváltás a NPM gyakorlatában háromféle orientáció mentén körvonalazódhat: az ún. „sigma” - értékek a gazdaságossággal és takarékossággal, a ",theta”- értékek a tisztességgel és korrektséggel, míg a „lambda”értékek a biztonsággal és rugalmassággal hozhatók öszszefüggésbe. Mindhárom típus közös jellemzője, hogy sajátos, egymástól sok tekintetben eltérő közelítésmódjuk ellenére egy-egy alapértéket fektetnek le, mint elsődlegesen követendő irányt. Az így meghatározott prioritások mindegyike az értékalapú menedzsment előtérbe helyezését hangsúlyozza a közszektor szemléletváltását presszionálva. Az 1. táblázat a három fó értékcsoport mentén mutatja be az egymás szélsőségeiként megjeleníthető siker/kudarc okait és kulcstényezőit; az 
A közmenedzsment sikertényezői

\begin{tabular}{|c|c|}
\hline $\begin{array}{l}\text { - Globális költségvetés periodikus bontásokkal } \\
\text { - Mutatószámok ellenőrzése } \\
\text { - Nyereség-/ költségközpontok } \\
\text { - Lízing, szponzorálás } \\
\text { - Köz-holdingok } \\
\text { - Részesedési/érdekeltségi controlling }\end{array}$ & $\begin{array}{l}\text { - Megegyezések, alkuk } \\
\text { - Szerződések } \\
\text { - A visszaható (reaktív) magatartásminták helyett a kreatívak } \\
\text { támogatása } \\
\text { - Ösztönzések, motiváció } \\
\text { - Rugalmas (élet)pálya } \\
\text { - Motiváló stratégiák a szervezettel való azonosulást illetően } \\
\text { - Vállalati kultúra és vállalati etika } \\
\text { - Funkció- és kompetencia-transzfer }\end{array}$ \\
\hline $\begin{array}{l}\text { - Eredmény-felelősség } \\
\text { - Költségvetés-felelősség } \\
\text { - Teljesítmény menedzsment }\end{array}$ & $\begin{array}{l}\text { - Ösztönzési rendszer } \\
\text { - Humán erőforrás (személyi) fejlesztés } \\
\text { - Mutatószámok- személyi vezetés („,laza” vezetés) }\end{array}$ \\
\hline \multicolumn{2}{|c|}{$\begin{array}{l}\text { A KÖZMENEDZSMENT SIKERTÉNYEZŐI } \\
\text { Célok: Megfogalmazás- Megvalósítás- Stabilizálás }\end{array}$} \\
\hline $\begin{array}{l}\text { - Ügyfél- és versenytudatosság } \\
\text { - Szolgáltatás-szellemiség }\end{array}$ & $\begin{array}{l}\text { - Lapos szervezet } \\
\text { - Komplexitás-mérséklés } \\
\text { - A teljesítés mélységének csökkentése }\end{array}$ \\
\hline $\begin{array}{l}\text { - Benchmarking } \\
\text { - (Állam)polgár-közeliség } \\
\text { - Ügyfél-/ vevő-megértés } \\
\text { - Szolgáltatás-ígéret } \\
\text { - Just in time } \\
\text { - Szolgáltatás standardok } \\
\text { - TQM a folyamat elejétől } \\
\text { - Marketing (innovatív szolgáltatásokkal és vonalbeli kiter- } \\
\quad \text { jesztéssel) } \\
\text { - Auditálás } \\
\text { - Belső verseny }\end{array}$ & $\begin{array}{l}\text { - Szinergiahatás } \\
\text { - Feladatredukálás } \\
\text { - Feladatdelegálás } \\
\text { a make or buy } \\
\text { a outsourcing } \\
\text { - Külön kompetenciák } \\
\text { - Erőforrás-felelősség } \\
\text { - Projektszervezet }\end{array}$ \\
\hline
\end{tabular}

Forrás: Damkowski - Precht, 1995: 77-80

A közmenedzsment ,értékrendszer-típusai”

\begin{tabular}{|c|c|c|c|}
\hline & ,Sigma"- értékek & ,THETA"-ÉRTÉKEK & ,LAMBDA"- ÉRTÉKEK \\
\hline & $\begin{array}{c}\text { Tervhez és takarékossághoz } \\
\text { való igazodás }\end{array}$ & $\begin{array}{c}\text { Tisztességhez és } \\
\text { becsületességhez való igazodás }\end{array}$ & $\begin{array}{l}\text { Határozottsághoz és } \\
\text { rugalmassághoz való igazodás }\end{array}$ \\
\hline A siker alapja & $\begin{array}{l}\text { Mértékletesség } \\
\text { (A kitűzött célok eléréséhez } \\
\text { szükséges feladatokhoz és ezek- } \\
\text { hez rendelt erőforrásokhoz) }\end{array}$ & $\begin{array}{l}\text { Becsületesség } \\
\text { (A korrektség, kölcsönösség, he- } \\
\text { lyes kötelességteljesítés elérése) }\end{array}$ & $\begin{array}{l}\text { Rugalmasság } \\
\text { (A rugalmasság, alkalmazkodás, } \\
\text { határozottság elérése) }\end{array}$ \\
\hline A sikertelenség oka & $\begin{array}{l}\text { Pazarlás } \\
\text { (Káosz, zavar, szakszerűtlenség) }\end{array}$ & $\begin{array}{l}\text { Korrupció } \\
\text { (Hivatali visszaélés, részrehajlás, } \\
\text { szabálytalanság) }\end{array}$ & $\begin{array}{l}\text { Kudarc } \\
\text { (Kockázat, csőd) }\end{array}$ \\
\hline $\begin{array}{l}\text { A siker és kudarc } \\
\text { érvényesülése }\end{array}$ & $\begin{array}{l}\text { Pénz és idő } \\
\text { (Az eljárások és a fogyasztók erő- } \\
\text { forrás-költségei) }\end{array}$ & $\begin{array}{l}\text { Bizalom és jogosítványok } \\
\text { (Beleegyezés, törvényesség, poli- } \\
\text { tikai jogosítványok) }\end{array}$ & $\begin{array}{l}\text { Biztonság és túlélés } \\
\text { (Magabiztosság) }\end{array}$ \\
\hline Az ellenőrzés súlypontjai & Output & Folyamat & Input/Folyamat \\
\hline A rugalmasság mértéke & Alacsony & Közepes & Magas \\
\hline Célok & Meghatározott célok & Összeegyeztethetetlen célok & Összetett célok \\
\hline Információ & Szegmentált információk & Strukturált információk & Információcsere \\
\hline Kapcsolat & Szoros & Közepes & Laza \\
\hline
\end{tabular}

Forrás: Hood, 1991: 11 
ellenőrzési és beavatkozási fókuszpontokat; az adott értékek követése mentén megengedhető rugalmasság mértékét; az adott értékrendszer kontextusában definiált célokat; a felhasználható és feldolgozandó információkat, valamint a priorált értékek követésének eredményeképpen kialakuló kapcsolat erősségét.

Az állam és polgára közötti új minőségű kapcsolatban ,az állam számít a közért tenni akaró, aktív polgárra, cserébe a közszolgáltatások terén is előtérbe kerül az átláthatóság, a számonkérhetőség, láthatóvá válik a szakmai fejlődés eredménye. Az állam meghatározza a standardokat, amelyeket a közszolgáltatás fogyasztói várhatnak és monitorozza a teljesítményt." (Dessewffy - Pulai, 2005: 20).

\section{Zárszó}

A közszféra speciális eszköz- és célrendszere, az államtól való teljes vagy részleges függősége, valamint a politikai, gazdasági, társadalmi érdekellentétek miatt a NPM gyakorlati alkalmazhatósága számos kérdést, kételyt vet fel. Kétségtelen, hogy nem hagyhatók figyelmen kívül e sajátos tényezők, mindazonáltal be kell látnunk, hogy a „vállalati versenyképesség” fogalom nem a magángazdaság privilégiuma. A közigazgatás, a közjogi szervezetek és a közszférában érdekeltek versenyben állnak más intézményekkel, melyek hasonló vagy azonos szolgáltatásokat, termékeket kínálnak. Ebből következik, hogy minden, a közszolgáltatásokban érdekelt vállalat, intézmény, szervezet számára a változásmenedzsment követelményei és kihívásai azonos módon érvényesek (Gattermeyer - Neubauer, 2000: 242). A NPM valódi üzenete nem a közszféra szervezeteinek a klasszikus értelemben vett piacgazdasági menedzsmentgyakorlat ,plagizálására” való buzdítás, hanem a versenyszféra alapvető mozgatórugóit (részlegesen) magában hordozó, újszerű menedzsmentformák létrehozása a közszektor működési sajátságainak és peremfeltételeinek figyelembevételével.

A NPM tehát nem gyógyszer és mindenekelőtt nem egy gyors megoldás a politikai-adminisztratív rendszerben évtizedenként kialakuló sikertelenségekre. A NPM egy eszköz lehet egy jobb közigazgatás-vezetés megvalósításához olyan módosított megoldási szempontokat kínálva a közszektor számára, amelyeket a magángazdaságban is használnak (Thom - Ritz, 2000: 24).

\section{Felhasznált irodalom}

Brunner-Salten, R. (2003): Handbuch Public Change Management; Effizientes Veränderungsmanagement für öffentliche Verwaltungen; Frankfurt am Main: Peter Lang $\mathrm{GmbH}$

Budäus, D. - Grüning, G. (1998): New Public Management. Entwicklung und Grundlagen einer „Revolution” des öffentlichen Sektors; In: Zeitschrift Führung + Organisation, 67. Jahrgang 1998, Nr. 1, 4-9.

Cseke, H. (2004): Nincs szó kínzásról! Sárközy Tamás a közigazgatás modernizációjáról. Figyelő. 2004/ 39 (2004. szeptember 30 október 6.)
Damkowski, W. - Precht, C. (1995): Public Management: Neue Steuerungs-konzepte für den öffentlichen Sektor; Stuttgart/Berlin/ Köln

Davey, K.- Péteri, G. (1998): Local Government Finances: Options for Reform; Nagykovácsi: Pontes Ltd

Dessewffy, T.- Pulai, A. (2005): Az álmatag állam ébresztgetése- a közszféra átalakulásának szükségessége. Figyelő. 2005/36 (2005. szeptember 8-14.)

Dunleavy, P.- Hood, C. (1994): From Old Public Administration to New Public Management; Public Money and Management, Vol. 14., 9-16.

Gattermeyer, W.- Neubauer, R. (2000): Das Neue Strategische Management; Elemente und Perspektiven zukunftsorientierter Unternehmensführung; Wiesbaden

Hajnal, Gy. (2004): Igazgatási kultúra és New Public Management reformok egy, összehasonlító esettanulmány tükrében; $\mathrm{PhD}$ értekezés; BKÁE Gazdálkodás- és Szervezéstudományi Doktori Program

Hambleton, R. - Savitch, H. V. - Stewart, M. (2002): Globalism and Local Democracy; Challenge and Change in Europe and North America; London: Palgrave MacMillan.

Heidrich, B.- Somogyi, A. (2005): Az elengedett kéz dilemmája, avagy a vezetők kulturális lehetőségei a szolgáltató és közigazgatási szervezetekben; Vezetéstudomány, XXXVI. Évfolyam, 9. szám (2005. szeptember), 2-14.

Hill, H. (1997): Strategische Erfolgsfaktoren in der öffentlichen Verwaltung. In: Qualitäts- und erfolgsorientiertes Verwaltungsmanage-ment, hrgs. V. Hermann Hill und Helmut Klages, 2. Aufl. Berlin.

Hood, C. (1991): A Public Management for all Seasons?; Public Administration, Vol. 69 Spring, 3-19

Horváth M., T. (2002): Helyi közszolgáltatások szervezése; Budapest-Pécs: Dialóg Campus Kiadó.

Illés, M. (2000): A közszolgáltató vállalatok gazdasági szabályozása; Elvek, módszerek, esetek. Budapest: Aula Kiadó Kft.

Kalas, T.- Ivancsics, I.- Torma, A.- Paulovics, A.- Bistei, A..- Varga, J. (2001): Közigazgatási jog -Általános rész-; Virtuóz Kiadó.

Kieser, A. (1998): Organisationstheorien; Stuttgart/Berlin/Köln.

König, K. (1995): „Neue” Verwaltungen oder Verwaltungsmodernisierung, -Verwaltungspolitik in den 90er Jahren-; Die öffentliche Verwaltung, 5/1995, 349-358.

Magyar Értelmező Kéziszótár (1985); Budapest: Akadémiai Kiadó.

Mueller, D. C. (1989): Public Choice II.; Cambridge

Osborne, D.- Gaebler, T. (1992): Reinventing Government -How the Entrepreneurial Spirit Is Transforming the Public Sector-; USA: Penguin Book

Pollitt, C. (1990): Managerialism and the Public Services: the Anglo-American Experience; Oxford, Cambridge

Reinermann, H. (1998): Neues Politik- und Verwaltungsmanagement in der kommunalen Praxis: Leitbild und Theoretische Grundlagen, Kapitel 1; in: Reinermann, H.- Thoenig, J-C. (1998): Neues Politik- und Verwaltungsmanagement in der kommunalen Praxis - ein internationaler Vergleich -, Sankt Augustin: Konrad-Adanauer-Stiftung e. V

Schedler, K. (2004): Wirkungsorientierte Verwaltungsführung: Begriffe und aktueller Stand der Entwicklung (Eredetileg megjelent: Pulitano, Donatello (2000): New Public Management. Terminoligie - terminologie- terminologia c. munkájában, Bern/Stuttgart/Wien: Paul Haupt, 33-47.)

Thom, N.- Ritz, A. (2000): Public Management, -Innovative Konzepte zur Führung im öffentlichen Sektor-; Wiesbaden: Betriebswirtschaftlicher Verlag Dr. Th. Gabler GmbH.

Torma, A. (2001): Európai közigazgatás, régiók, önkormányzatok; Virtuóz Kiadó

Viscusi- Vernon- Harrington (1995): Economics of Regulation and Antitrust. Cambridge/ Massachusetts/ London: The MIT Press.

Walsh, K. (1995): Public Services and Market Mechanisms Competition, Contracting and the New Public Management-; London: MacMillan Press Ltd

Zielinski, H. (2003): Management im öffentlichen Sektor; Opladen: Leske \& Budrich. 